\title{
U ČEMU JE MEDICINSKA TAJNA DUGOVJEČNOSTI
}

\section{Sařetak}

Starost i starenje nisu sinonimi. Starenje je normalan fiæiološki proces koji počinje odmah nakon rodenja, nepouratan je $i$ u pojedinaca napreduje razlicitom brz̨inom. Starost se definira godinama života (bronološko vrijeme). Biološko starenje obubvata promjene u funkcijama organizma tijekom vremena, usporavanje $i$ opadanje funkcija. Psihološko starenje - vlastita procjena starenja, odnosno mentalne reakije koje prate iskustvo starenja. Socijalno (društveno) starenje - način na koji osobe do:̌ivljavaju starenje u odnosu prema društvu. Dužina življenja ovisi o: nasljednim osobinama (genskoj strukturi), specifićnostima okoline (kvaliteti riviljenja) i u najvé́oj mjeri, o sretnim ili nesretnim okolnostima. Starenje ubrzavaju: pušenje, alkohol, neodgovarajuća prehrana, droga, smanjena tjelesna aktivnost, sistemske bolesti ( metabolickee, endokrinoloskke, imunološke). Učešce starijih od 65 i više u 2005. godini u BiH 14, 4\%, a u 2050. procjena je 33, 8\%. Za osiguranje što duljeg života neophodno je usporiti propadanje stanica u svim situacijama na koje možemo osobno utjecati, kako bismo usporili intenzitet replikacija genoma (tj. usporili trošenje telomera), a time onda produljili život pojedinih vrsta thiva $i$ cijelog organizma. Zanimljivo je da se mjerenjem durine telomera na uzorcima iz periferne krvi moře puno toga očitati, primjerice predispozicija za starenje, te bolesti $i$ tegobe povezane sa starenjem. Svaki covjek ima telomere, a znanstvenici su ih opisali kao male čvorove na krajevima hromosoma koji ib čnvaju od raspadanja. Kod nekoga su duře, kod nekoga kraće. To ovisi o genetici covjeka. Znači, ako u familiji ima dugovječnih, velika je šansa da će nasljednici imati dug život, imat će dư̌e telomere za dulji život.

Ključne riječi: dugovječnost, telomera, način rivota.

\section{Uvod}

Jedan od najatraktivnijih ciljeva u povijesti čovječanstva jeste dugovječnost. Svi alhemičari svijeta su tragali za eliksirom života, a moćnici na sve strane slali karavane istraživača u potrazi za tajnim recepturama dugog života. S individualnog stanovišta i sa socioekonomskog gledišta, važno je prilagoditi život godinama i godine

${ }^{1}$ Visoka zdravstvena škola 
životu. Zdravlje stoji na nekoliko ključnih stupova: pravilna prehrana, kretanje, socijalizacija, pozitivan stav prema životu, ali i zdravi geni. Postoje mnoge fizičke, psihičke, socijalne promjene i promjene u okolišu koje se javljaju s godinama. Hronične bolesti i oštećenja kao što su artritis, hipertenzija i moždani udar, srčana oštećenja, respiratorni problemi, dijabetes, rak i osteoporoza, mogu djelovati na kvalitetu života starije populacije.

Proces starenja objašnjavaju brojne teorije:

1. Genetske teorije: teorija pogreške, teorija somatske mutacije, teorija programiranog starenja;

2. Fiziološke teorije starenja: teorija slobodnih radikala, teorija unakrižne povezanosti, teorija nakupljanja otpadnih tvari;

3. Imunološka teorija;

4. Neuroendokrinološka teorija starenja. ${ }^{(1,2)}$

\section{Da li je tajna dugovječnosti skrivena u telomerama?}

Jedna teorija koja u novije vrijeme privlači sve veću pažnju je teorija dugovječnosti skrivena u telomerama i u funkciji enzima telomeraze. Prilikom obnavljanja tkiva dolazi do diobe ćelija i replikacije genoma. Na krajevima hromosoma nalaze se zapisi TTAGGG koji se ponavljaju i po hiljadu puta. Taj dio hromosoma je telomera. Prilikom svake diobe dolazi do skraćivanja telomera, što zapravo označava proces starenja ćelija a time i cjelokupnog organizma. S prestankom dijeljenja ćelije ne umiru, nego nastavljaju živjeti, ali pokazuju promijenjena biohemijska svojstva i opisujemo ih kao stare ćelije. Ćelije koje se ne dijele, ili se dijele sporo, zastupljenije su u organizmu starije dobi. Ovom osnovnom principu ne podliježu ćelije u kojima je zadržana funkcija enzima telomeraze čija zadaća je obnova telomernih nizova. 


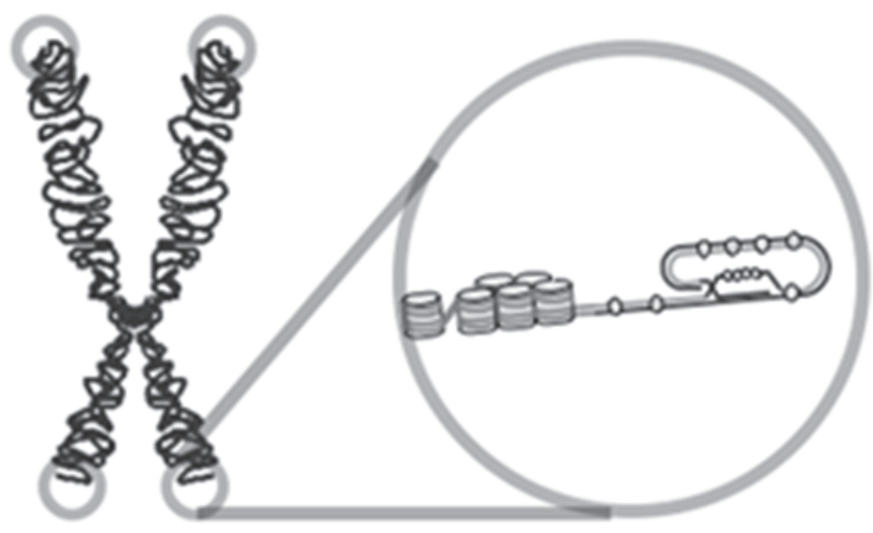

Slika 1. Telomera

Telomere su kratki ponovljeni nizovi nukleotida na kraju hromosoma

Izvor: http://images.google.com/imgres?q=telomera

Enzim telomeraza aktivan je u matičnim ćelijama embrija, spolnim ćelijama, krvotvornim ćelijama (bijele krvne stanice - leukociti), ali nažalost i u tumorskim ćelijama. U ostalim ćelijama receptori za enzim telomerazu su blokirani. Deblokiranjem tih receptora na ćelijama drugih vrsta tkiva značilo bi pojavu besmrtnosti, ali ona za sada još nije moguća, iako postoje brojni pokušaji produljenja života kod osoba kod kojih je došlo do oštećenja organa bez kojih život nije moguć. $\mathrm{Na}$ osnovu ovih spoznaja, može se zaključiti da nam je unaprijed brojem replikacija DNA molekule određena najveća moguća duljina života, a danas se smatra da je to oko 120 godina. Načinom života može se utjecati na brže ili sporije oštećenje ćelija i time starenja ćelija i čitavog organizma.

\section{Značaj telomera za dugovječnost}

Telomere su zaštitni krajevi hromosoma. One sprječavaju hromosomsko habanje i uređene su strukture na krajevima hromosoma. Od su iznimnog su značenja za stabilnost genoma. Telomere su odgovorne za programiranje genetske informacije, ili još preciznije, skraćivanje telomere može se smatrati kao biološki sat koji predviđa životni vijek ljudi. Procjenjuje se da ljudske telomere izgube oko 100 parova baza DNK tokom svake mitoze (ćelijske diobe). Nakon približno 125 mitoznih podjela, telomere potpuno nestaju što je razlog zašto 
normalne ćelije nestaju - ugibaju. Kraća telomera znači i kraći život ćelije. Ćelije zadržavaju duljinu telomera svojim enzimom telomerazom. Duljina telomera se određuje pomoću omjera genetskog materijala sadržanih u jezgri bijelih krvnih ćelija (T-Ly) i telomere u odnosu na duljinu jednog kopiranja gena poznatih veličina za hronološku dob. Ako je aktivnost telomeraze visoka, duljina telomera se održava a ćelijsko starenje se odgada. Skraćivanje telomera ide ruku pod ruku s procesom starenja. To je otkrio prof. Lenhard Hayflick 1961. i ustvrdio da ćelija ima limit u diobi (taj limit je nazvan Hayflick-Limit). Istraživanja u USbased ćasopisu Biological Psychiatry su pokazala da djeca koja su imala emocionalno traumatsko djetinjstvo, koja su seksualno zlostavljana ili premlaćivana, imaju tendenciju da imaju kraće telomere. Održavanje duljine telomere postiže se izbjegavanjem svakog oblika stresa: fizičkog, ekološkog i psihološkog, jer je za dugovječnost bitno održavanje odgovarajuće dužine telomere. Gubitak telomera je katastrofalan za ćeliju te uzrokuje njezinu smrt i lomove hromosoma. Telomeraza može produžiti telomere i održavati ih na optimalnoj dužini tako da se ćelije kojima je to potrebno mogu dijeliti u nedogled kao matične, spolne, ali i one tumorske ćelije. To bi moglo uvelike pomoći u novim pokušajima pronalaska lijeka za rak. Telomere su i odlični indikatori dugovječnosti, bolesti i podložnosti stresu. Stres znatno skraćuje telomere i smanjuje aktivnost telomeraze, što je prisutno i kod ljudi sa hipertenzijom, dijabetesom i osteoporozom. Tjelesna aktivnost, pravilna i zdrava ishrana i upražnjavanje socijalnih vještina pozitivno utječu na telomerazu.

Na smanjenje duljine telomere utječe: upalna stanja, oksidativni stres, rafinirani ugljikohidrati, brza hrana (fast food), procesuirana hrana, umjetna sladila, zasićene masti, kardiovaskularne bolesti, inzulinska rezistencija, dijabetes, hipertenzija, ateroskleroza, demencija.

Na održavanje duljine telomera utječu: angiotenzin konvertaze angiotenzina (inhibitori ACEI). Blokatori angiotenzinskih receptora, inhibtori renina, statini, blokatori kalcijskih kanala, aldosteron u serumu receptor antagonisti, upotreba metformina, aspirin, hormonsko nadomjesno liječenje, smanjenje LDL holesterola za oko $70 \mathrm{mg} \%$, smanjiti oksidirani LDL, povećanje HDL na više od $40 \mathrm{mg}^{\%} \mathrm{u}$ muškaraca i više od $50 \mathrm{mg}^{\circ}$ u žena i povećati HDL 2 subfraction, smanjiti upalne HDL i povećanje zaštitnog HDL, smanjiti razinu glukoze u krvi na manje od $90 \mathrm{mg} \%$ i 2 sata objavite prandial ili 2 sata GTT na manje od $10 \mathrm{mg} \%$, održanje hemoglobina $\mathrm{A}_{1} \mathrm{C}$ na oko 5,0 posto $\mathrm{i}$ zadržati nisku razinu inzulina, smanjiti krvni tlak na oko $120 / 80 \mathrm{~mm}$ 
$\mathrm{Hg}$, smanjenje homocisteina na manje od 8 um / L, smanjenje HS-CRP na manje od 1,0, održavanje idealne tjelesne težine. (3)

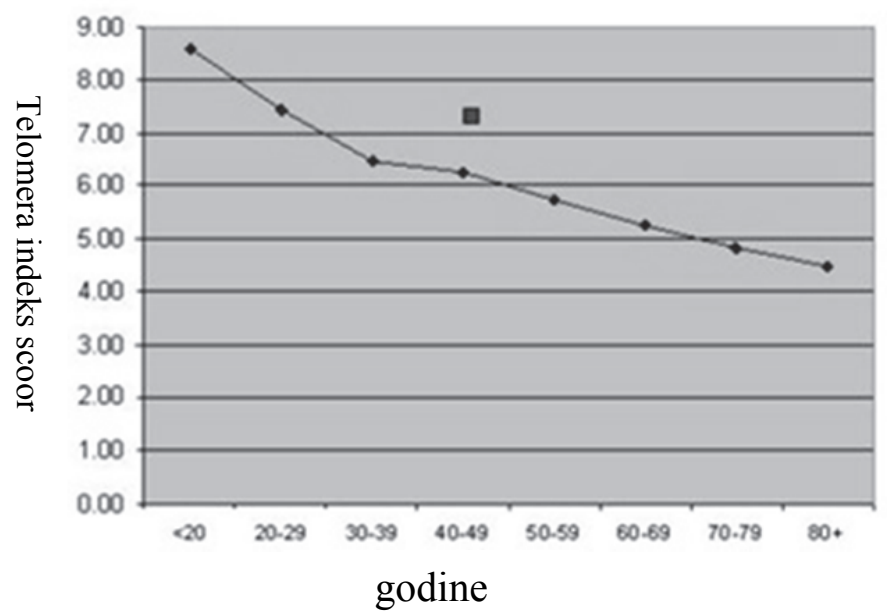

Slika2. Grafički prikaz opadanja telomera tokom života.

Godine starosti, score index telomera i prosjek indeks scora tolomera za pojedine godine

\section{Izvor:}

http:/ /images.google.com/imgres?q=Sample+telomere+graph

Brojni procesi mogu ubrzati starenje:

1. izloženost organizma jačim dozama radioaktivnog zračenja,

2. dugotrajno izlaganje ultraljubičastim zrakama (Sunce ili umjetni izvori),

3. opekline ili ozebline,

4. intoksikacija organizma raznim hemikalijama,

5. mehaničke tjelesne povrede (traume),

6. teški tjelesni napori koji drže organizam u anaerobnim uslovima,

7. izostanak tjelesne aktivnosti,

8. izloženost teškim psihičkim i emocionalnim stanjima, ali i dugotrajna izloženost stresu, 
9. hormonalni poremećaji između uravnoteženih antagonističkih parakrinih hormona (prostaglandina) dovode do razvoja upalnih procesa, slabljenja imunološkog sistema organizma koji postaje podložniji bolestima uzrokovanih mikroorganizmima, ali i dolazi do razvoja autoimunih bolesti,

10. hormonalni poremećaji u ravnoteži endokrinih hormona kao što su inzulin i glukagon, kao posljedica neprimjerenog načina života (neadekvatne prehrane, slabe tjelesne aktivnosti, pojačane izloženosti stresu),

11. dehidracija organizma, koja ne samo da dovodi do oštećenja stanica nego i do oslabljenog čišćenja organizma od toksina nastalih u biohemijskim procesima,

12. neuravnotežena i siromašna prehrana sa manjkom makro i mikro nutrijenata nužnih za rad ćelija,

13. gomilanje slobodnih radikala u organizmu.

\section{Čovjek stari onako kako je živio, kaže kineska poslovica.}

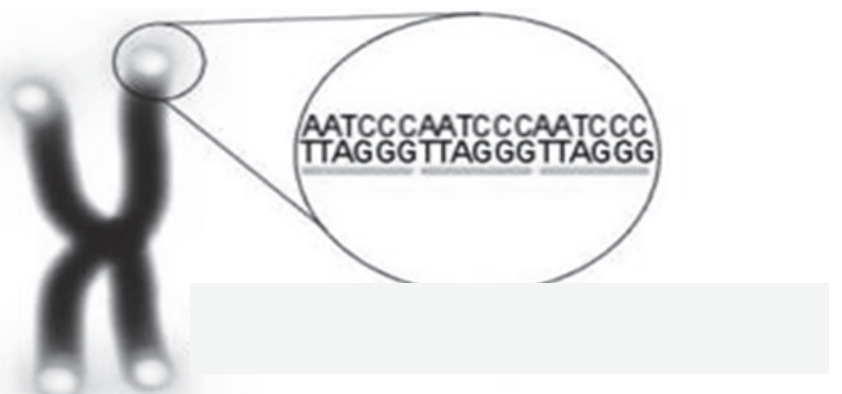

Slika 3. Prikaz sadržaja ljudske telomere.

Ljudske telomere sadrže hiljade ponavljanja u šest sekvenci nukleotida TTAGGG

Izvor: http:/ /images.google.com/imgres?q=telomere\&hl=hr\&

Poznata je sintagma: cjeloživotna briga o načinu života: vježbanje, u jelovnik uvesti što više voća i povrća, dovoljno odmora. U studiji iz 2009. dobitnica Nobelove nagrade iz biologije dr. Elizabeth $\mathrm{H}$. Blackburn i dr. psihologije Elissa S. Epel, sa Univerziteta Kalifornija u San Franciscu, otkrili su da hronični stres doslovno nagriza DNK - taćnije njegove vrhove, telomere, $i$ ubrạava starenje stanice. Zapravo, dr. Singer kaže: 
Žene koje osjećaju da su pod stalnim stresom imaju kraće telomere - njihova je duřina jednaka onoj koju bi řene trebale imati tek qa 10 godina. Savremena znanstvena disciplina koja se bavi područjem imuniteta i starenja, tzv. epigenetika, raspolaže obiljem dokaza da je disregulacija ljudskog imunološkog sistema čest pokretač većine bolesti koje su povezane sa starenjem. Svako stari drukčrje, čak i jednojajčani blizanci. ${ }^{2}$ Znanstvene studije su pokazale da blizanci s godinama postaju sve različitiji, što se zove epigenetski dinamizam. Različiti ljudi, pa i blizanci, žive različitim životima te zbog toga različito i stare. Način i brzina starenja nisu unaprijed zadani, oni ovise o mnogim faktorima. Životno iskustvo, stil života i već spomenuti epigenetski utjecaji danas se čine važnijim od faktora vremena i samoga genetskoga naslijeđa. Slabljenje imunološkog sistema naziva se imunosenilnost, pri čemu je stres važan okidač. Razliciti tipovi stresa znanstveno dokazano vode slabljenju aktivnosti obrambenih NK-stanica (Natural Killer - prirodni ubojica) koje su nam potrebne za odbranu od raka, srčanih $i$ virusnih oboljenja te mnogih drugih bolesti. ${ }^{3}$ Desetljećima su znanstvenici i liječnici znali za snažan zdravstveni i nutritivni potencijal skriven u neobrađenom zrnu riže. Rižine mekinje sadrže molekule zvane arabinoksilani, poznate po povoljnom djelovanju na imunitet ljudi. No, uzimanjem samih rižinih mekinja ne postiže se potpuna iskoristivost hranjivih tvari. Imunostimulatori (immune-boosters) podižu razinu imunoloških funkcija, što je problematično za ljude čiji je imunološki sustav već prekomjerno aktivan. Imunoregulatorne funkcije, bilo jačanje ili održavanje imunološke aktivnosti, kao neophodne za opće zdravlje djeluju tako da osnažuju narušeni imunitet, no mogu i prekomjerno stimuliran imunološki sistem vratiti u ravnotežu. Jedan od najvažnijih faktora u ljudskom životu svakako je način prehrane. Mnoge bolesti naše civilizacije nastaju ponajprije zbog loše ili posve pogrešne ishrane, pa se u Kini najčešće drže gesla: Neka vaša hrana bude lijek, neka vaš lijek bude brana.

Četiri su osnovna pravila drevne kineske kulture prehrane:

1. čovjek svaki dan mora uzimati tri obroka, s tim da je doručak najobilniji, ručak osrednji, a večera najskromnija,

2. radi zaštite zdravlja, zimi treba u velikim količinama jesti ciklu i drugo povrće, dok se u ljetno doba preporučuje korijen đumbira,

\footnotetext{
2 www.vasezdravlje.com

${ }^{3}$ Isto
} 
3. pravi melem za želudac i crijeva je juha od đumbira koja se uzima ujutro, a navečer, kada organizam miruje, treba izbjegavati đumbir,

4. manje soli, više kiselina, manje šećera, više voća - pravilo je kreposti i zdravlja. ${ }^{(4,5,6)}$

Faktori za postizanje duljeg života

1. Stalna tjelesna aktivnost - u svim životnim razdobljima od mladosti do duboke starosti, od 85 i više godina;

2. Stalna psihička aktivnost - u primjeni doživotnog učenja, neumijeće stjecanja novih vještina i znanja zbog starosti i starenja ne bi trebalo biti opravdanje;

3. Pravilna mediteranska prehrana koja je restrikcijska po kalorijskoj vrijednosti za starije od 65 godina (nikako veći unos od 1500 kcal, s obzirom na smanjenje bazalnog metabolizma u starijih osoba). To uključuje redovito uzimanje povrća i voća, ribe, bijelog mesa bez kožice; bez unosa "4B" u hrani: bijelo brašno, bijeli šećer, sol, bijela mast; unos do dvije litre dnevno nezaslađene tekućine (najbolje čiste vode), umjerena konzumacija crnog vina (ne više od decilitar i po dnevno uz obrok);

4. Nepušenje i neovisnost o alkoholu, opijatima, lijekovima, crnoj kahvi i dr.;

5. Stalna radna aktivnost uključuje preorijentacijsko zanimanje za nove radne aktivnosti i nakon umirovljenja, ali i pozitivnu zdravstvenu, socijalnu i radnu politiku koja omogućuje produljenje radnog vijeka;

6. Vjerovanje $u$ sebe i budućnost dugovječnog življenja, optimistično poimanje osobnih i okolišnih uslova življenja;

7. Iskazivanje pozitivnih emocija i ljubavi za posao koji se obavlja, za obitelj i za mlade i starije oko sebe te umijeće svladavanja novih vještina i prihvaćanja novih spoznaja;

8. Izbjegavanje osamljenosti i socijalne izolacije zbog nesuglasja sa životnim događanjima;

9. Samodisciplina i samoodgovornost u odnosu na pridržavanje pozitivnog zdravstvenog ponašanja te na redovitost spavanja, ličnu čistoću i higijenu; ne traženje krivnje za vlastite neuspjehe u drugima; 


\section{Neprihvaćanje stereotipa i predrasuda o starenju i starosti kao}

beskorisnosti, bolesti, nemoći i ovisnosti o drugima, već ponosno isticanje starosti i starenja kao normalne fiziološke pojave u kojoj funkcionalna sposobnost pojedinog 75-godišnjaka može biti toliko očuvana da se ne razlikuje od funkcionalne sposobnosti 55godišnjaka.

11. Kao što je jasno vidljivo iz navedene tabele Mogući riquicni faktori iz mesa, negativne su posljedice obilate zbog upotrebe tih namirnica i mnogo češće se manifestiraju problemi u obliku hroničnih degenerativnih bolesti poput kardiovaskularnih i zloćudnih bolesti, šećerne bolesti i slično, nego kao infektivne bolesti kojih se mnogi boje. Spomenute hronične degenerativne bolesti vrlo su raširene i njima se ne narušava samo kvaliteta življenja konzumenata mesa, već se skraćuje i njihova očekivana duljina života. Bilo kako bilo, nakon svih povijesnih i savremenih dokaza, ostaje nam jasan zaključak da upotreba mesa i mesnih proizvoda nije preporučljiva za dobro zdravlje i dug život! U svim kulturama i podnebljima svi će se složiti kako fast food nije zdrava hrana. Sve to, dugoročno, deblja i zakrečuje krvne žile, povisuje tlak. ${ }^{(7)}$

\section{Starenje i prosječno trajanje života}

Starenje je životni proces postupnog i nezaustavljivog pogoršavanja i propadanja organizma kojim se ujedno skraćuje život (što se više stari, veća je vjerojatnost umrijeti). Svaki bi čovjek stario i kada ne bi bilo bolesti, ali bolesti prate čovjeka tokom cijeloga života pogoršavajući mu zdravlje, čime se mijenja način starenja i trajanje života, što se osobito odnosi na infarkt srca, moždani udar i rak, zbog kojih mnogi ljudi žive znatno kraće. Prosječno trajanje života (u razvijenim zemljama) danas je oko 75 godina, a kada bi se uspjelo spriječiti te najčešće smrtonosne bolesti, prosječno bi se živjelo najmanje 10 godina duže, dakle oko 85 godina. Ljudi različito stare: prerano, normalno ili usporeno, što zavisi od dviju skupina međusobno povezanih faktora (o kojima ovisi zdravlje, odnosno bolesti). Riječ je o slijedećim faktorima:

a) faktori naslijeđa (genetski čimbenici, tj. naslijeđeni ispravni ili defektni geni, ćelije, tkiva, organi, tjelesni sistemi i mehanizmi) i 
b) faktori okoline (način življenja, zvanje kojim se bavimo, doticaj s nezdravim okolišem, štetna zračenja, stresne situacije i dr.).

Tabela 1: Mogući rizični faktori iz mesa

\begin{tabular}{|c|c|}
\hline SASTOJAK & $\begin{array}{c}\text { MOGUĆI RIZIK } \\
\text { OBOLIJEVANJA OD: }\end{array}$ \\
\hline \multicolumn{2}{|l|}{ MASNOĆE IZ MESA: } \\
\hline $\begin{array}{c}\text { Zasićene masnoće } \\
\text { Odnos mnogostruko nezasićenih i } \\
\text { zasićenih masti }\end{array}$ & $\begin{array}{l}\text { Kardiovaskularne bolesti, rak } \\
\text { šećerna bolest, rak }\end{array}$ \\
\hline \multicolumn{2}{|l|}{ BJELANČEVINE: } \\
\hline $\begin{array}{c}\text { Nitrati } \\
\text { Heterociklički amini } \\
\text { ŽELJEZO } \\
\text { FOSFOR }\end{array}$ & $\begin{array}{l}\text { Rak } \\
\text { Rak, kardiovaskularne bolesti } \\
\text { Rak, kardiovaskularne bolesti } \\
\text { Osteoporoza, frakture }\end{array}$ \\
\hline \multicolumn{2}{|l|}{ DODACI TOKOM UZGOJA: } \\
\hline $\begin{array}{c}\text { Hormoni (estradiol, testosteron, } \\
\text { progesteron) } \\
\text { Antibiotici } \\
\text { Hrana zaražena prionima }\end{array}$ & $\begin{array}{l}\text { Upale rezistentnim } \\
\text { bakterijama } \\
\text { Kreutzfeldt-Jacobsova bolest }\end{array}$ \\
\hline \multicolumn{2}{|l|}{$\begin{array}{l}\text { ADITIVI/ZARAZE PRI } \\
\text { KONZERVIRANJU: }\end{array}$} \\
\hline $\begin{array}{c}\text { Nitrati, nitriti } \\
\text { Procesi soljenja i sušenja mesa } \\
\text { E. coli, salmonela, trihineloza }\end{array}$ & $\begin{array}{l}\text { Rak } \\
\text { Rak } \\
\text { Infekcija }\end{array}$ \\
\hline \multicolumn{2}{|l|}{$\begin{array}{c}\text { SPOJEVI NASTALI TIJEKOM } \\
\text { PRIPREME: }\end{array}$} \\
\hline $\begin{array}{c}\text { Benzopireni } \\
\text { Ostali policiklički aromatski } \\
\text { ugljikovodici }\end{array}$ & $\begin{array}{l}\text { Rak } \\
\text { Rak }\end{array}$ \\
\hline
\end{tabular}

Općenito se može reći da faktori okoline ovise uglavnom o samom čovjeku. Starenje uglavnom počinje u dobi od 40 do 45 godina. Zbog starenja ljudi postaju stariji, a prema definiciji Svjetske zdravstvene organizacije, starije osobe su osobe u dobi 60 do 75 godina, stare osobe su osobe u dobi 76 do 90 godina, a vrlo stare osobe su one iznad 90 godina. Vjerojatna maksimalna granica čovjekova života je oko 120 godina. U razvijenim zemljama, oko polovica ljudi doživljava 75 - 80 godina života, a ljudi najviše umiru između 70 - 80 godina. Prerana smrt znači umrijeti prije 70 . godine života, a dugovječnost obično znači živjeti 
duže od 75 (ili 80) godina, pri čemu je vrlo važno doživjeti krepku starost, odnosno starost uz dobru psihofizičku kondiciju i sačuvanu sposobnost prilagođavanja stresovima. Od ljudi koji su postigli visoku životnu dob, tj. dugovječnost, čak $90 \%$ potječe od dugovječnih roditelja, što je dokaz o tome kako je važno naslijediti ispravne (a ne defektne) gene, tkiva, organe i tjelesne sisteme, odnosno zdravu konstituciju. Povoljna je okolnost da negativno naslijeđe (onaj dio koji je bitan za zdravlje, starenje i dugovječnost) pogađa samo manji broj ljudi, naime, oko $96 \%$ djece rađa se bez genetskih bolesti i bez većih razvojnih nepravilnosti. Osim toga, od dugovječnih roditelja ne samo što se nasljeđuje zdrava konstitucija, nego se, vjerojatno, može naučiti šta je ispravan način življenja (pravilna prehrana, tjelesna aktivnost, nepušenje, umjerenost u svemu i dr. ). Za svakog je čovjeka najvažnije pitanje u vezi sa starenjem: Kako ga usporiti uz što duže trajanje zdravog života? Da bi se to postiglo, potreban je ispravan način življenja, što obuhvaća, kao glavno (uz primjenu načela umjerenosti u svemu), pravilnu prehranu s održavanjem stalne težine što bliže idealnoj, tjelesnu aktivnost (svakodnevno hodanje barem 30 minuta i dr.), nepušenje, nepijenje alkoholnih pića prekomjerno, boravak na čistom zraku izvan prostorija dnevno jedan do dva sata, redovito spavanje $7-8$ sati, umjeren rad $i$ dovoljno odmora. Također, vrlo je važno biti psihološki i emocionalno uravnotežen, uz pozitivno gledanje na svijet. ${ }^{(8)}$

\section{Starenje i način prehrane}

Svi se gerontolozi i drugi istraživači starenja i dugovječnosti slažu u tome da u načinu prehrane treba tražiti glavni odgovor na pitanje kako usporiti starenje i živjeti duže uz dobro zdravlje. Mnoga su istraživanja, koja traju već 70 godina, pokazala da u mnogih životinjskih vrsta (ptica, riba, štakora, majmuna i dr.) smanjenje kalorija u pravilnoj prehrani ima za posljedicu znatno produženje života (npr. u riba za 300\%, u štakora za $60 \%$, u majmuna za 30\%), uz bitno poboljšanje njihova zdravlja i smanjivanje hroničnih bolesti (osobito krvožilnih i zloćudnih), a nema razloga vjerovati da bi s ljudima bilo bitno drukčije. Također, brojne tzv. epidemiološke studije (kod etničkih skupina Hunza, Vilcabamba, stanovnika Okinawe i dr.) pokazuju kako se uz pravilnu prehranu, s ograničenim kalorijama oko 1300 do 1700 , postiže zdrav život, usporava starenje i postiže dugovječnost uz mnogo manje srčano-žilnih, moždanožilnih i zloćudnih bolesti. Ima više objašnjenja o tome zašto se zbog povećanih kalorija u prehrani skraćuje trajanje života. Prema jednom 
objašnjenju, glavni su uzrok slobodni radikali. Naime, kada se prekomjerno jede kalorična hrana, u tijelu se stvara previše slobodnih radikala (molekule štetnog oblika kisika), koji svojim oksidirajućim djelovanjem oštećuju i uništavaju tjelesne ćelije (i njihov DNK), odnosno krvne žile i druga tkiva i organe, čime se bitno doprinosi preranom starenju, kao i nastanku i razvoju ateroskleroze, infarkta srca, moždanog udara, raka i drugih poremećaja i bolesti (mnogo slobodnih radikala ulazi u tijelo izvana, npr. udisanjem duhanskog dima $\mathrm{i}$ ispušnih motornih plinova, od sunčanih i drugih zračenja, od pesticida). Iz mnogih istraživanja proizlazi da je za zdrav život, usporeno starenje i dug život potrebna pravilna prehrana i, u okviru pravilne prehrane, unos kalorija manji za 30 do 40\%, tako da prehrana daje oko 1400 do 1700 kalorija (evropska prehrana daje prosječno oko 2500 - 2800 kalorija).

Neko živi kraće, a neko duže. Skraćeno trajanje života imat će uglavnom ljudi kojima način življenja nije ispravan (ne hrane se pravilno, puše, prekomjerno piju alkoholna pića, žive neurednim životom itd.), zatim ljudi koji zbog teških pogrešaka u prehrani (tri najčešće teške pogreške: neumjerenost u jelu i piću, tj. previše kalorija, previše masnoća u hrani i premalo povrća i voća) dobiju i mnogo prije godina starosti infarkt srca, moždani udar ili rak. Drugi razlozi zbog kojih se živi kraće (naslijeđeni defektni geni i naslijeđena nezdrava konstitucija, stresne situacije, štetna zračenja i dr.) ipak su relativno rjedi i imaju manji utjecaj nego neispravan način življenja i teške pogreške u prehrani. Zdravlje probavnog sistema je ključ za postizanje sveukupnog zdravlja organizma. Koliko je dobra naša probava - toliko ćemo imati energije, a o tome ovisi i stanje duha i tijela kao i naša dugovječnost. Probavne smetnje javljaju se u svim dobnim skupinama. Najčešći problemi vezani uz zdravlje probavnog sistema su loša probava, crijevne zaraze, nadimanje i upale (sindrom iritabilnog kolona, ulcerozni kolitis, gastritis, Chronova bolest), nepravilno pražnjenje crijeva (zatvor, proljev) itd. ${ }^{(9)}$

\section{Osnov sprječavanja dugovječnosti -"upala"}

Bez upalnog procesa prisutnog u tijelu ne postoji način da se holesterol nakupi u stjenkama krvnih žila i da uzrokuje srčane bolesti i moždani udar. Bez upalnog procesa holesterol bi slobodno cirkulirao po cijelom tijelu. Upala je ta koja uzrokuje da holesterol ostane zarobljen u krvnim žilama. Upala je jednostavno prirodna odbrana našeg tijela protiv napadača kao što su bakterije, toksini ili virusi. To je savršen način kako 
se naše tijelo štiti od ovih bakterijskih i virusnih napadača. Međutim, ako hronično izlažemo tijelo ozljedama od toksina ili od hrane za koju naše tijelo nije stvoreno da je prerađuje, tada nastaje stanje hronične upale. Hronična upala (inflamacija) je isto toliko štetna, koliko je akutna (trenutna) upala korisna.

\section{Izazivači hronične upale su:}

1. pretjerana upotreba visoko prerađenih ugljikohidrata (šećer, brašno i svi proizvodi napravljeni od njih),

2. pretjerana upotreba biljnih ulja bogatih omegom 6 (sojino, kukuruzno i suncokretovo ulje - ulja koja se nalaze u velikom broju industrijskih prerađevina),

3. hrana natrpana šećerom i ugljikohidratima, procesuirana s omega 6 mastima radi produžene trajnosti, predstavlja okosnicu američke prehrane zadnjih 6 desetljeća.

Nije dobro ako se poremeti omjer omega masnih kiselina. Naime, prekomjernim unošenjem omege 6 , ćelijske membrane proizvode hemijske spojeve citokine koji izravno uzrokuju upalu. Mnogi proizvodi danas imaju omjer između omege 6 i omege 3 15:1 pa do 30:1, što dovodi do ogromne količine citokina koji uzrokuje upale. U današnjim uslovima, omjer od 3:1 bi bio optimalan za zdravlje.

\section{Otkriveni geni za kontrolu steroidnih hormona}

Znanstvenici su otkrili osam gena koji kontroliraju razinu steroidnih hormona za koje se vjeruje da su uključeni u starenje i dugovječnost. Otkriveni geni kontroliraju koncentraciju dihidroepiandrosteron sulfata (DHEAS) u krvi, hormona čija se koncentracija rapidno smanjuje starenjem. Prijašnja istraživanja pokazala su da se razina DHEAS smanjuje za 95\% do dobi od 85 godina, a smatra se da to smanjenje doprinosi nekim bolestima povezanim sa starenjem. Geni su otkriveni nakon pomne analize razine DHEAS-a i genetskog profila gotovo 15,000 ljudi iz Evrope i SAD-a. ${ }^{(10)}$

\section{ZAKLJUČCI}

1. Ko želi živjeti zdravo, usporiti starenje i dugo živjeti u dobroj kondiciji, treba slijediti slijedeće savjete: 
Hraniti se pravilno, jer je to prvi i osnovni uslov da srčano-žilni, imunološki, hormonalni i drugi tjelesni sistemi funkcioniraju ispravno, bez značajnijih poremećaja. U okviru pravilne prehrane treba smanjiti kalorije na oko 1400 za žene, a oko 1700 za muškarce.

2. U okviru pravilne prehrane treba se hraniti namirnicama za koje je brojnim medicinskim, biohemijskim i drugim znanstvenim studijama ustanovljeno da sprječavaju nastanak i razvoj krvo-žilnih i zloćudnih bolesti koje najčešće skraćuju život. To su antikancerogene tvari (antioksidansi, vitamini C, E i beta-karoten, minerali selen i cink, flavonoidi i drugi biljni pigmenti, antienzimi inhibitori proteaza, elagična, klorogenična i neke druge organske kiseline), biljna vlakna (brokula, kupus, kelj i drugo kupusno povrće, mrkva, tikva, tikvice, blitva, špinat, zelena salata, šparoga, paprika, maslačak, cikorija), povrće i voće bogato beta-karotenom, plave ribe, čajevi od šipka, metvice, ružmarina, kadulje, majčine dušice.

3. Ne pušiti i ne piti prekomjerno alkoholna pića.

4. Prilagoditi se stresnim situacijama kako bi se suzbile štetne posljedice stresa:

tehnika opuštanja (duboko disanje, mišićno opuštanje, masaže i sl.), tjelesnim vježbama i fizičkim radom; redovita umjerena tjelesna aktivnost, smanjenje napetosti, depresije, neraspoloženja, umora.

5. Dovoljno odmora, spavanja.

6. Kretanje, kretanje i samo kretanje.

7. Kalcij za treću dob (piti 4 šolje mlijeka) unositi 800-1200 mg kalcija.

8. Gimnastika za mozak, čitanje.

9. Redovite liječničke kontrole.

10. Treba promijeniti način života, okrenuti se tjelovježbama, zdravom režimu prehrane i što manjoj izloženosti stresu kako bi na taj način očuvali svoje telomere i postigli što dugovječniji i ispunjeniji život.

\section{Literatura:}

1. Hayflick, Leonard: How and Why We Age. New York: Ballantine Books, 1996.

2. Kendić S. i saradnici: Gerijatrijska njega, Visoka zdravstvena škola Bihać, 2010. (str.19-37) 
3. Rubelj, Ivica: Dinamika telomera tijekom starenja i kancerogeneze (Telomere dynamics in senescence and carcinogenesis), 2. hrvatski gerontološki kongres s međunarodnim sudjelovanjem. Opatija, 2006.,

4. Ferenac, Marina: Dinamika skeracivanja telomera u kontroli staničnog starenja (Dynamics of telomere shortening in cell senescence), Sveučilište u Zagrebu, Zagreb (diseratcija), 2005.

5. Linus, Pauling: Kako živjeti dulje $i$ osjećati se bolje (How to live louger and fell better). Globus-Zagreb, 1, (prevod), 1986.

6. Rubelj, Ivica: Telomere kao glavni mehanizam kontrole procesa starenja. Skup: Novi dometi u dijagnostici i terapiji - era globalnih analitičkih metoda, Simpozij u povodu 40. obljetnice Kabineta za istraživanje i standardizaciju imunoloških supstancija. Zagreb, 2010.

7. Bodnar, A. G., et al. Extension of Life Span by Introduction of Telomerase intoNormal Human Cells. Science 279 (1998.): 349-352.

8. Greider, Carol W. Telomeres and Senescence: The History, the Experiment, the Future. Current Biology 8: 178-181, 1998.

9. The Illusion of Cell Immortality: British Journal of Cancer, 83 841-846, 2000.

10. Zhai G., Teumer A., Stolk L., Perry JRB, Vandenput L., et al. (2011) Eight Common Genetic Variants Associated with Serum DHEAS Levels Suggest a Key Role in Ageing Mechanisms. PLoS Genet 7(4): e1002025. doi:10.1371/journal.pgen.1002025 


\section{Sulejman Kendić, PhD}

\section{WHAT IS A MEDICAL SECRET OF LONGEVITY}

\section{ABSTRACT}

Age and aging are not synonymous. Aging is a normal physiological process that begins immediately after birth, is irreversible and individuals progresses at different rates. Age is defined by years of life (chronological time). Biological aging, includes changes in the functions of the body during the time, the slowdown and the decline all functions. Psychological aging, proper evaluation of aging and mental reactions that accompany the experience of aging. Social aging, the way people perceive aging in relation to society. Length of life depends on inherited traits (genetic structure), the specifics of the environment (quality of life) and to the fullest extent of the fortunate or unfortunate circumstances. Accelerate aging: smoking, alcohol, inadequate nutrition, drugs, decreased physical activity, systemic diseases (metabolic, endocrine, immune).Participation of the old people of 65 and over in 2005 was $14.4 \%$ in Bosnia and Herzegovina, but the estimate in 2050 it will be 33.8\%. To ensure the long life it is necessary to slow the deterioration of cells, in all situations in which we can personally affect, so we slow down the intensity of replication of the genome (i.e. to slow spending telomeres), and thereby extend the life of certain types of tissue and whole organism.Interestingly, by measuring telomere length in peripheral blood samples we can read a lot, for example, a predisposition to aging, diseases and problems associated with aging. Every man has the telomeres, and scientists have described them as small knots on the ends of chromosomes that protect them from decay. Someone has longer telomeres and someone has shorter ones, depending on the genetics of man. So, if the family has long-lived members, there is a chance that the heirs will have a long life, will have longer telomeres for longer life.

Key words: longevity, telomere, a way of life. 
الأستاذ الدكتور سليمان كينديتش

\section{ما هو سر طبي لطول العمر}

\section{الخلاصة}

ليست الشيخوخة مرادفاً للتقدم في السن. التقدم في السن هي عملية فيزيائية

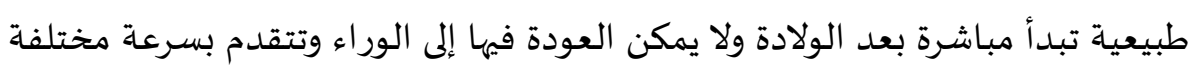

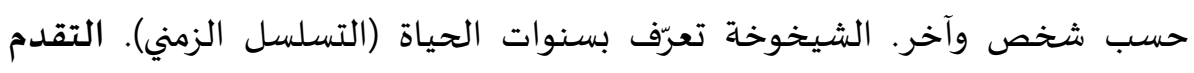

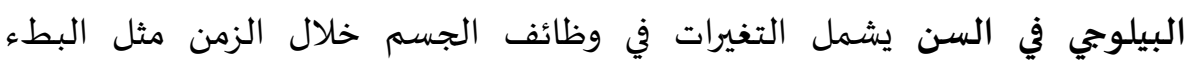
والضعف. التقدم النفسي في السن هو التقدير الذاتي للتقدم في السن أي ردود الأفعال العقلية التي تصحب عملية التقدم في السن. التقدم الاجتماعي في السن هو كيف يتعامل الإنسان مع تقدمه في السن مقارنة بالمجتمع.

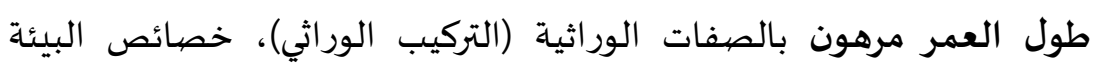

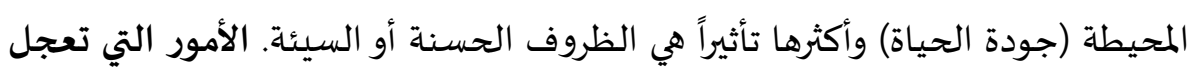

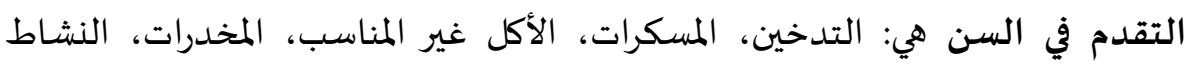

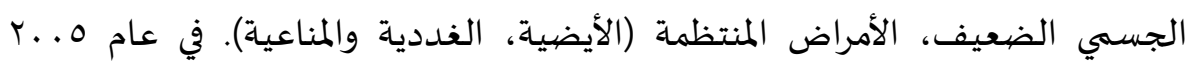

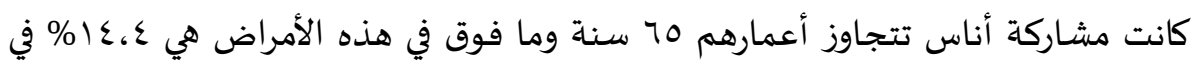

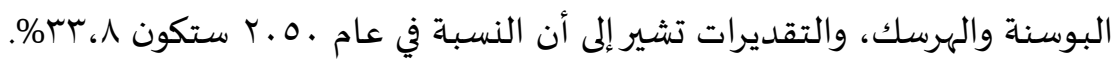

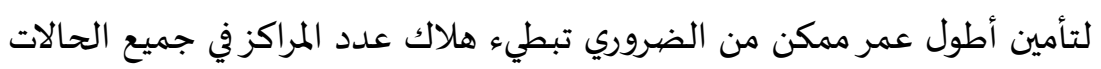

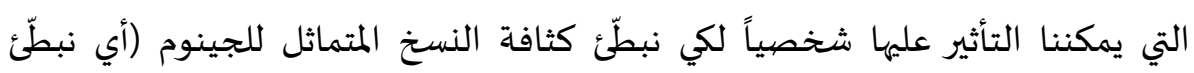

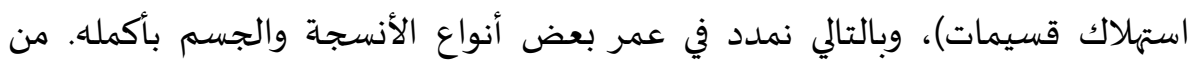

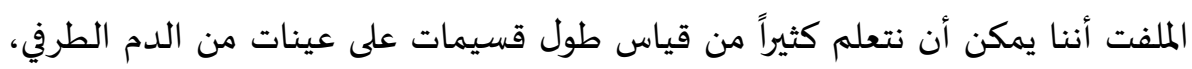

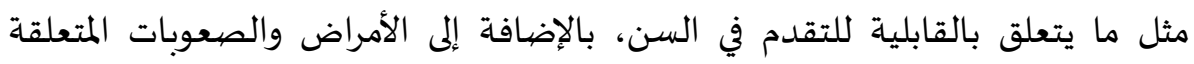

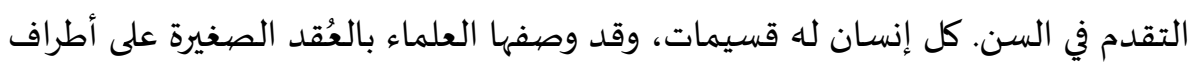

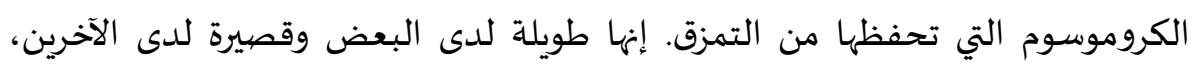

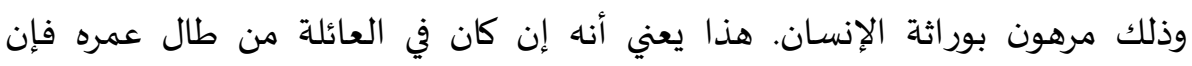

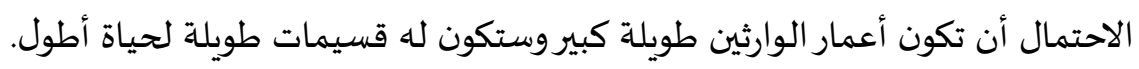

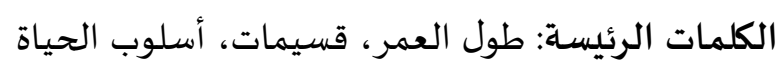

